GEOLOGICA BALCANICA, 49 (2), Sofia, August 2020, pp. 25-38.

\title{
Assessing the ground waters of Bulgaria using a Water Quality Index
}

\author{
Tanya Vasileva \\ Geological Institute, Bulgarian Academy of Sciences, Acad. G. Bonchev Str., Bl. 24, 1113 Sofia, Bulgaria; \\ e-mail: tanyav@geology.bas.bg
}

(Accepted in revised form: July, 2020)

\begin{abstract}
The study focuses on the quality of shallow groundwater in Bulgaria based on the content of major ions. To be safe for drinking purposes, their concentrations must not exceed the respective thresholds. The groundwater quality is assessed in terms of health hazard by a groundwater quality index (GWQI or WQI), and the respective map is presented. The results show that for the territory of Bulgaria, this index varies from 13 to 92 . The highest values of this index (related to health hazard) are typical for the lower hypsometric zone of the country. The shallow groundwater in the zone of active water exchange is distributed as follows: waters of excellent quality, waters of good quality, waters of poor quality, and waters of very poor quality, covering $3 \%$, 39\%, $22 \%$, and $31 \%$ of the whole area of the country, respectively. In this study, no estimates have been made for $5 \%$ of the territory of Bulgaria, which is characterized by the presence of very hard groundwater.
\end{abstract}

Vasileva, T. 2020. Assessing the ground waters of Bulgaria using a Water Quality Index. Geologica Balcanica 49 (2), 25-38.

Keywords: water quality index, groundwater quality, major ions, water type, Bulgaria.

\section{INTRODUCTION}

In nature, water moves in a continuous cycle. During this cycle, various substances dissolve, and therefore its composition is complex. When it falls on the earth's surface, rainwater increases its mineralization by dissolving a number of substances both organic and inorganic, determining the quality of groundwater, and the possibilities for its usage for various purposes. The Regulation on the Quality of Drinking Water is a provision that describes the desired condition of any water intended for drinking and domestic use. Drinking water can be defined as water for both drinking and domestic use - either in its natural state or after the necessary processing, and is intended for drinking, food preparation and other household usage, regardless of its origin.

Thus, in order to be drinkable, water must meet the values of the indicators, as specified by the Regulation, and be safe and clean (i.e., harmless to human health). It should be mentioned that, if the content of individual substances in the water does not exceed the permissible upper limits set by standards, this still does not mean that the water can be used for drinking and domestic usage. Water quality can also deteriorate by all the adverse effects of substances and impurities, which are individually below the permissible concentrations. This requires the creation of an integrated groundwater quality assessment tool.

It should be noted that the present research makes an initial integrated regional assessment of the situation regarding the content of macro-components in the shallow groundwater of Bulgaria. The objective of this study is to investigate the ground waters from the hypergenic zone on the territory of Bulgaria. And the overall aim is to present an integrated qualitative assessment of their chemical status in terms of their major ion content.

\section{DESCRIPTION OF THE AREA}

The study area includes the whole territory of Bulgaria, which is approximately $111,000 \mathrm{~km}^{2}$. The country is located in the south-east corner of Europe, occupying the eastern part of the Balkan Peninsula. Bulgarian topography can be described as mostly 
flat and hilly (about 70\% of the area), with most plains located in the north and the south-east of the country. The average altitude of the country is about $470 \mathrm{~m}$, and five types of elevation can be described: lowlands (0-200 m), plain-hillish (201-600 m), low-mountainous (601-1000 m), mid-mountainous (1001-1600 m), and alpine (1601-2925 m) (see Fig. 1). The climate in Bulgaria is moderately continental, with the maximum precipitation occurring in the months of May and June, and the minimum in February. The southernmost parts of the country fall into the continental-Mediterranean climatic zone, characterized by high precipitation values during the fall-winter season and severe droughts in the summer. The average rainfall varies from about $450-500 \mathrm{~mm}$ in some areas to $1,000-1,400 \mathrm{~mm}$ in the higher mountainous regions (Koleva and Peneva, 1990). The average maximum long-term air temperature is $+14{ }^{\circ} \mathrm{C}$ (measured in July and $\mathrm{Au}-$ gust), and the minimum is $-3^{\circ} \mathrm{C}$ (in January) (Kyuchukova, 1983).

\section{Geological setting}

Bulgaria has a very complex geological structure (Dabovski et al., 2002), and widespread existence of varied rock formations with ages from the Precambrian to the Quaternary (Cheshitev et al., 1989). These rocks possess various surface exposure and distribution, and present different types of filtration, media for the groundwater (pore, karst) and fissures (Antonov et al., 1960) (Fig. 2). Quaternary

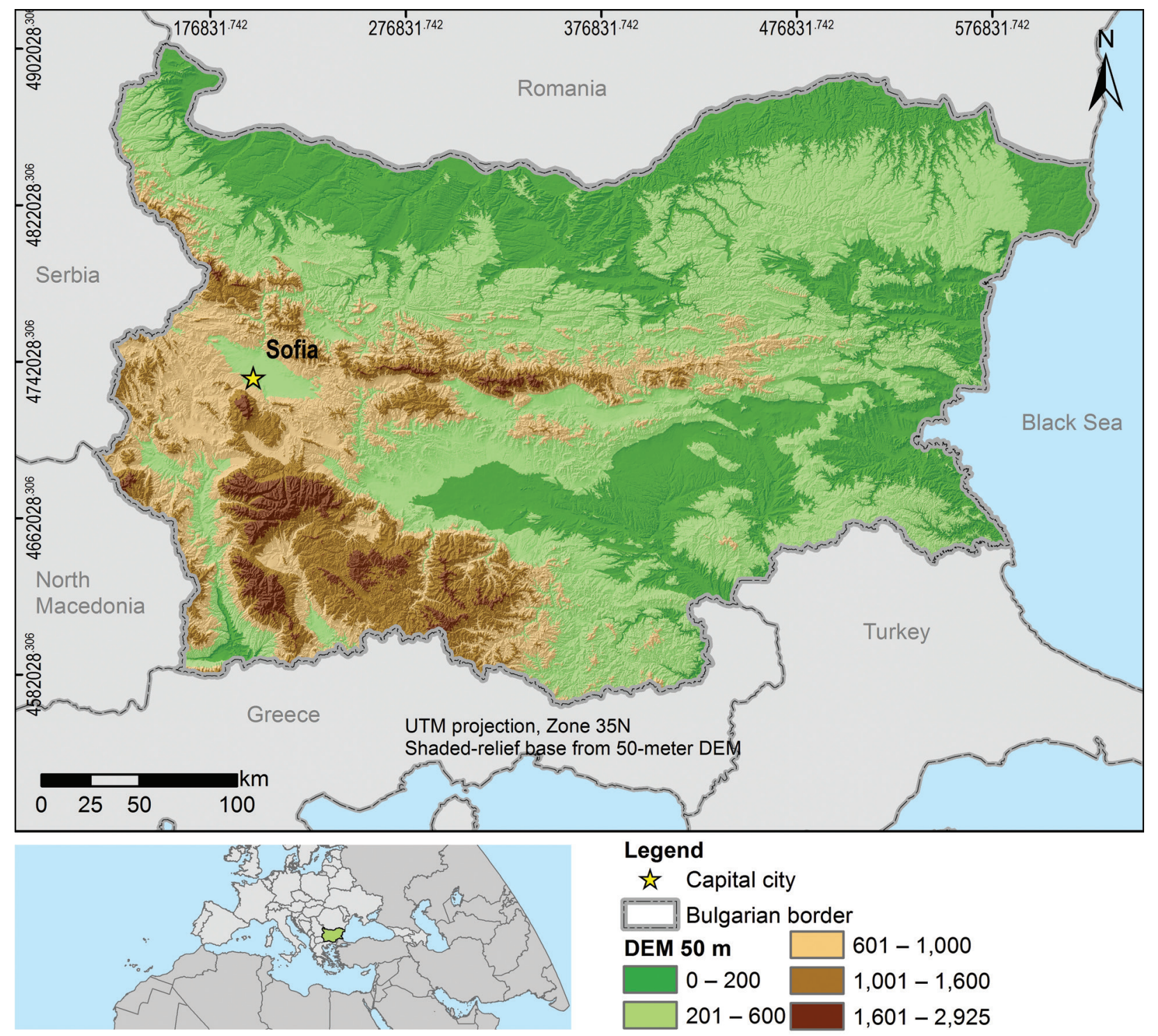

Fig. 1. Location of the study area and topographic map of Bulgaria. 


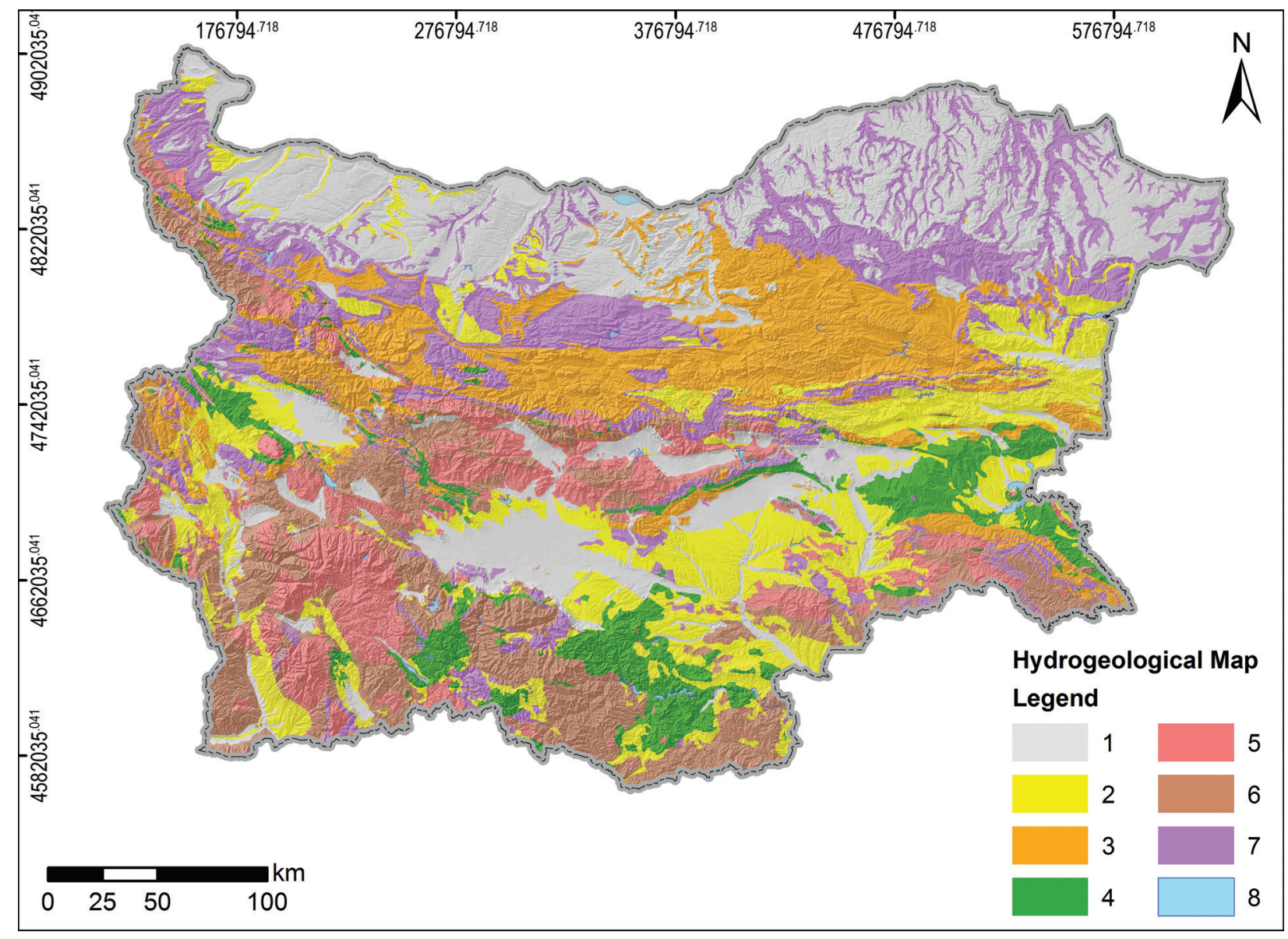

Fig. 2. Hydrogeological map of Bulgaria (after Cheshitev and Kanchev, 1989). Legend: 1 - Distribution of Quaternary unconsolidated deposits with porous water; 2 - Surface deposits of Neogene and Paleogene water-saturated rock complexes with porous aquifers; 3 - Weathering and fracture zones in solid sedimentary rocks with fissured water; 4 - Volcanic and volcano-sedimentary rocks with fissured water; 5 - Intrusive rocks with fissured waters in areas of regional cracking; 6 - Metamorphic rocks with fissured water in areas of regional cracking; 7 - Karst and fissured-karst water in sedimentary rocks; 8 - Water bodies.

deposits, including deluvial, eolian and alluvial, occupy almost the entire northern part of the country, where loess cover is also widespread. The depth of the loess deposits decreases southwards, from about $40-50 \mathrm{~m}$ in close proximity to the Danube River to 3-5 $\mathrm{m}$ at the Fore-Balkan Mts (Minkov, 1968). According to their genesis, pre-Quaternary rocks in Bulgaria are magmatic (intrusive, effusive and pyroclastic), sedimentary and metamorphic.

Geological conditions play a major role in shaping the composition of groundwater, as well as in the rock-water interaction processes. According to their origin, mineralogical and petrographic composition, the rocks contain chemical components in different concentrations, which affect the natural chemical composition of groundwater. In other words, the composition of groundwater depends on both the characteristics of the rocks, with which the water has been (or presently is) in contact, and the rock-water interaction. The processes of interaction between rocks and water have already been studied in the literature (e.g., Malov, 2004; Elanqo and Kannan, 2007; Stoyanov, 2019).

Presently, there has been done much research regarding the quality of groundwater in Bulgaria, but most of it has been of local character, concerning only certain geographic areas and water bodies. Some data for the overall chemical composition of the various types of water on the territory of Bulgaria can be found in regional summaries, as well as in reference books (Lechev et al., 1968; Stefanov, 1979). A number of processed results, including a compilation of different types of hydrochemical maps, were published by Kehajov (1968, 1970, 1972, 1978, 1979a, b, 1981, 1982, 1984a, b), and Kehajov et al. (2002). The publication regarding the role of the geological influences on the formation of the chemical composition of groundwater in Bulgaria was given by Gerginov et al. (2019). 
The results of several monitoring observations and other hydrochemical studies, focused mainly on the ecological status of groundwater, have been summarized in the River Basin Management Plans, and can be seen on the websites of the Bulgarian Ministry of Environment and Waters and the Basin Directorates. As characteristic features of all previous studies, it can be concluded that they are all based on estimates of separate indicators and make no use of integrated results.

\section{DATA USED IN THE STUDY}

The data used in the present study for the macro ions in the groundwater from the hypergenic zone in Bulgaria was published by Kehajov (1968). The major ions making up the main part of the mineralization of fresh groundwater, and determining its geochemical appearance and suitability for various purposes, include the following: bicarbonates, sulfates, chlorides, calcium, magnesium, sodium and potassium $\left(\mathrm{HCO}_{3}^{-}, \mathrm{SO}_{4}^{2-}, \mathrm{Cl}^{-}, \mathrm{Ca}^{2+}, \mathrm{Mg}^{2+}, \mathrm{Na}^{+}\right.$and $\mathrm{K}^{+}$). As already mentioned above, the data used herein (Table 1) for the average content of major ions in the groundwater was taken from Kehajov (1968). The average chemical composition was obtained from 2,016 analyses of water samples taken from different water points, such as springs, wells, drainages and boreholes, that are comparatively evenly distributed all over the territory of Bulgaria. For the purposes of this research, the total hardness is taken as the sum total of calcium and magnesium ions in meq/l, and the total mineralization is presented as the sum total of all ingredients in $\mathrm{mg} / \mathrm{l}$ (Table 1). All data presented below was obtained by Kehajov (1968) and digitized by the author in GIS environment.

\section{PHYSICAL-CHEMICAL PARAMETERS USED IN THE STUDY}

From the analyses of the water samples performed by Kehajov (1968) of the water samples taken from groundwater in the hypergenic zone, the waters on the territory of Bulgaria can be divided into six categories by their total hardness and, for each category, the average macro-chemical composition can be determined. Accordingly, the groundwater of the country can be divided as follows: very soft water (3\%); soft water (24\%); moderately hard water (15\%); rather hard water (22\%); hard water (31\%); and very hard water (5\% of the whole studied area). The distribution of these categories on the territory of Bulgaria is shown in Fig. 3, from which it can
Table 1

Data used in the study area

\begin{tabular}{|c|c|c|c|}
\hline $\begin{array}{c}\text { Type of } \\
\text { water }\end{array}$ & Parameters & $\begin{array}{c}\text { Average } \\
\text { value, } \mathrm{mg} / \mathrm{l}\end{array}$ & $\begin{array}{c}\text { Average } \\
\text { value, meq/l }\end{array}$ \\
\hline \multirow{8}{*}{ 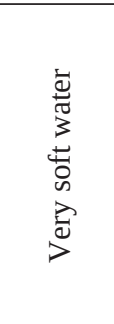 } & $\mathrm{Na}+\mathrm{K}, \mathrm{mg} / \mathrm{l}$ & 9.2 & 0.400 \\
\hline & $\mathrm{Ca}, \mathrm{mg} / \mathrm{l}$ & 16.7 & 0.833 \\
\hline & $\mathrm{Mg}, \mathrm{mg} / \mathrm{l}$ & 5.3 & 0.436 \\
\hline & $\mathrm{Cl}, \mathrm{mg} / \mathrm{l}$ & 5.7 & 0.161 \\
\hline & $\mathrm{SO}_{4}, \mathrm{mg} / \mathrm{l}$ & 12.3 & 0.256 \\
\hline & $\mathrm{HCO}_{3}, \mathrm{mg} / \mathrm{l}$ & 75 & 1.229 \\
\hline & TH, meq/l & 1.3 & 1.269 \\
\hline & TDS, mg/l & 124.2 & 0.400 \\
\hline \multirow{8}{*}{ 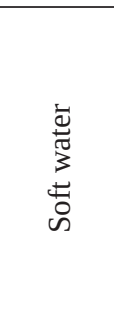 } & $\mathrm{Na}+\mathrm{K}, \mathrm{mg} / \mathrm{l}$ & 14.8 & 0.644 \\
\hline & $\mathrm{Ca}, \mathrm{mg} / \mathrm{l}$ & 44 & 2.196 \\
\hline & Mg, mg/l & 9.8 & 0.806 \\
\hline & $\mathrm{Cl}, \mathrm{mg} / \mathrm{l}$ & 11.3 & 0.319 \\
\hline & $\mathrm{SO}_{4}, \mathrm{mg} / \mathrm{l}$ & 20.6 & 0.429 \\
\hline & $\mathrm{HCO}_{3}, \mathrm{mg} / \mathrm{l}$ & 177 & 2.901 \\
\hline & $\mathrm{TH}, \mathrm{meq} / \mathrm{l}$ & 3.0 & 3.002 \\
\hline & TDS, mg/l & 277.5 & 0.644 \\
\hline \multirow{8}{*}{ 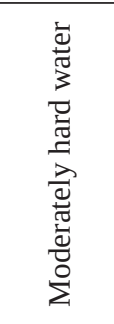 } & $\mathrm{Na}+\mathrm{K}, \mathrm{mg} / \mathrm{l}$ & 17.2 & 0.748 \\
\hline & Ca, mg/l & 64.3 & 3.209 \\
\hline & Mg, mg/l & 15.7 & 1.292 \\
\hline & $\mathrm{Cl}, \mathrm{mg} / \mathrm{l}$ & 12.1 & 0.341 \\
\hline & $\mathrm{SO}_{4}, \mathrm{mg} / \mathrm{l}$ & 16.8 & 0.350 \\
\hline & $\mathrm{HCO}_{3}, \mathrm{mg} / \mathrm{l}$ & 278 & 4.556 \\
\hline & $\mathrm{TH}, \mathrm{meq} / \mathrm{l}$ & 4.5 & 4.501 \\
\hline & TDS, mg/l & 404.1 & 0.748 \\
\hline \multirow{8}{*}{ 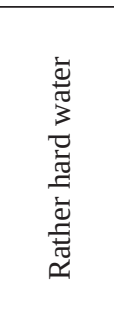 } & $\mathrm{Na}+\mathrm{K}, \mathrm{mg} / \mathrm{l}$ & 19.6 & 0.853 \\
\hline & $\mathrm{Ca}, \mathrm{mg} / \mathrm{l}$ & 84.2 & 4.202 \\
\hline & Mg, mg/l & 21.9 & 1.802 \\
\hline & $\mathrm{Cl}, \mathrm{mg} / \mathrm{l}$ & 16 & 0.451 \\
\hline & $\mathrm{SO}_{4}, \mathrm{mg} / \mathrm{l}$ & 14.4 & 0.300 \\
\hline & $\mathrm{HCO}_{3}, \mathrm{mg} / \mathrm{l}$ & 372 & 6.097 \\
\hline & $\mathrm{TH}, \mathrm{meq} / \mathrm{l}$ & 6.0 & 6.004 \\
\hline & TDS, mg/l & 528.1 & 0.853 \\
\hline \multirow{8}{*}{ 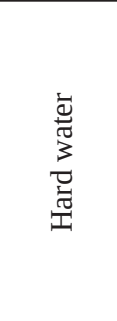 } & $\mathrm{Na}+\mathrm{K}, \mathrm{mg} / \mathrm{l}$ & 39.1 & 1.701 \\
\hline & $\mathrm{Ca}, \mathrm{mg} / \mathrm{l}$ & 81.2 & 4.052 \\
\hline & Mg, mg/l & 60.2 & 4.954 \\
\hline & $\mathrm{Cl}, \mathrm{mg} / \mathrm{l}$ & 55 & 1.551 \\
\hline & $\mathrm{SO}_{4}, \mathrm{mg} / \mathrm{l}$ & 55.1 & 1.147 \\
\hline & $\mathrm{HCO}_{3}, \mathrm{mg} / \mathrm{l}$ & 488 & 7.998 \\
\hline & $\mathrm{TH}, \mathrm{meq} / \mathrm{l}$ & 9.0 & 9.006 \\
\hline & TDS, mg/l & 778.6 & 1.701 \\
\hline
\end{tabular}

be seen that the total hardness of water decreases with the average altitude, and vice versa. The same trend applies to the total dissolved solids, i.e., the total dissolved solids in water increases with the decrease in the average altitude.

For the territory of Bulgaria, the concentrations of basic components found in groundwater have been found to vary widely (see Table 1, Figs 4-9). For instance, the hydrocarbonate content varies from $75 \mathrm{mg} / \mathrm{l}$ to $488 \mathrm{mg} / \mathrm{l}$, and it has the most vari- 


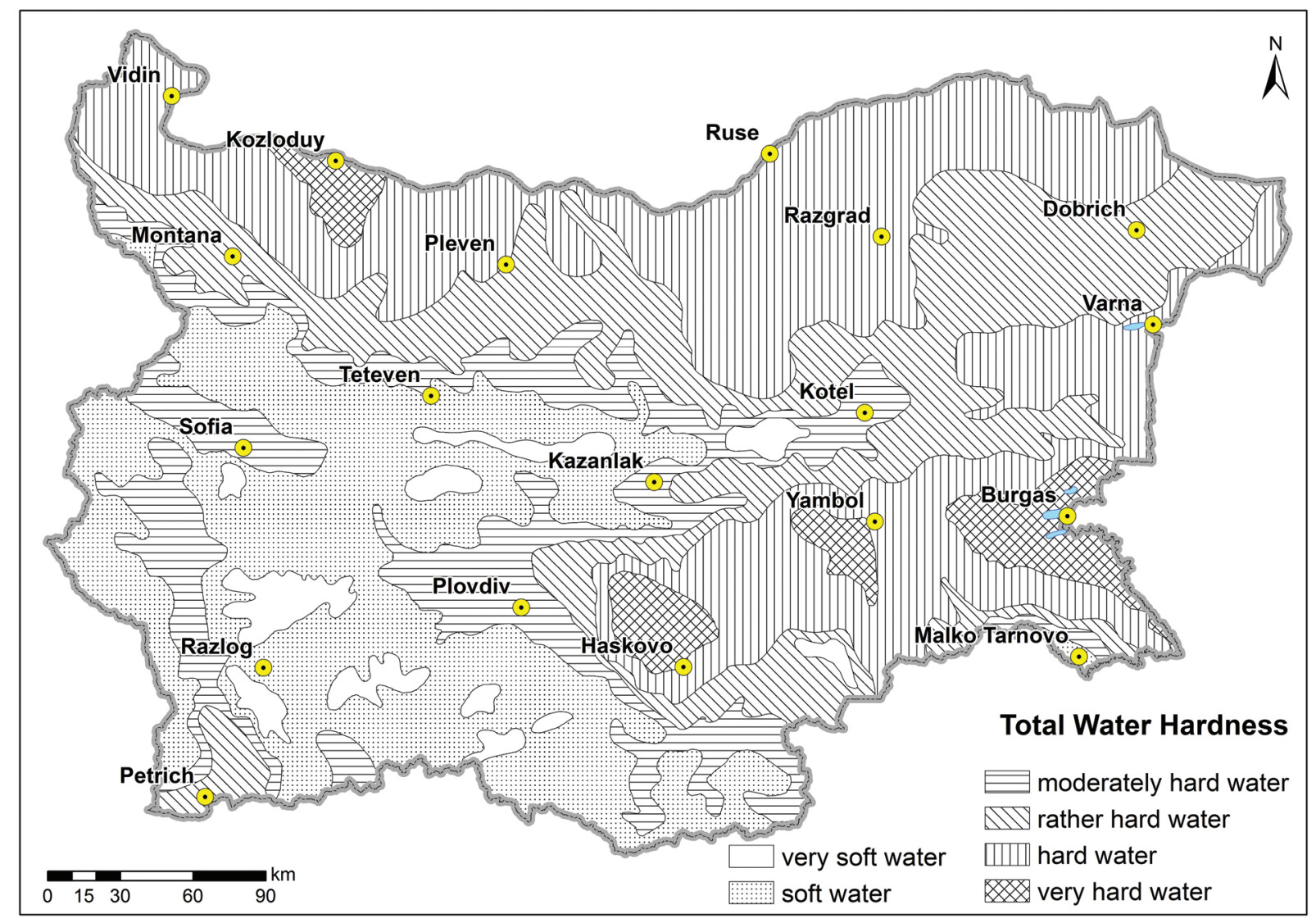

Fig. 3. Digitalized map showing the spatial distribution of the total water hardness for the study area, based on data of Kehajov (1968).

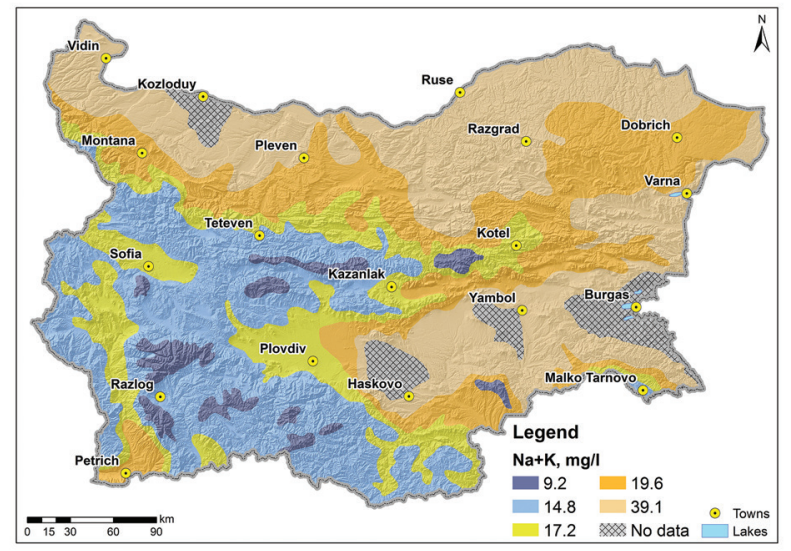

Fig. 4. Average groundwater chemistry in the study area (sodium and potassium).

able anion concentration, followed by the presence of chlorides and sulphates. Chlorides vary from $5.7 \mathrm{mg} / \mathrm{l}$ to $55.0 \mathrm{mg} / \mathrm{l}$, and sulphates vary from $12.3 \mathrm{mg} / \mathrm{l}$ to $55.1 \mathrm{mg} / \mathrm{l}$. The main dominant cation is calcium, the concentration of which varies in the

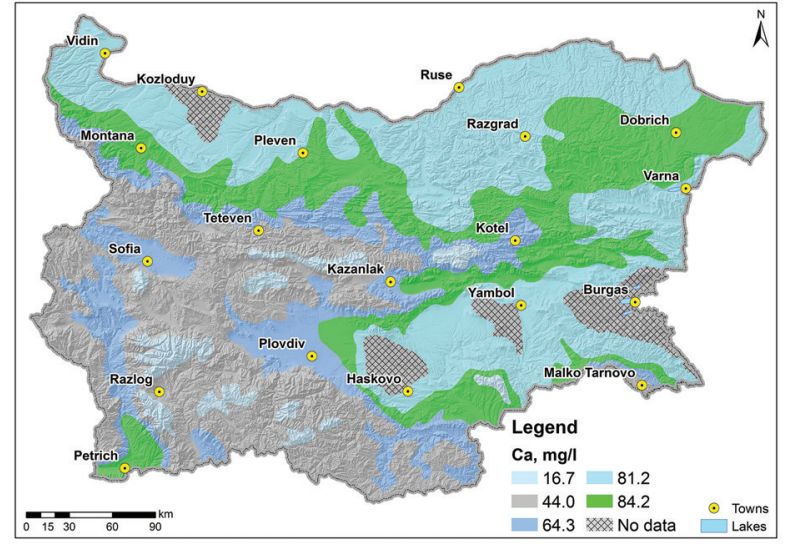

Fig. 5. Average groundwater chemistry in the study area (calcium).

range of $16.7 \mathrm{mg} / \mathrm{l}$ to $84.2 \mathrm{mg} / \mathrm{l}$. Magnesium varies from $5.3 \mathrm{mg} / \mathrm{l}$ to $60.2 \mathrm{mg} / \mathrm{l}$, and only in the hard groundwater does it dominate over calcium. The rapid increase in the concentration of major ions can be seen with any decrease in altitude, leading 


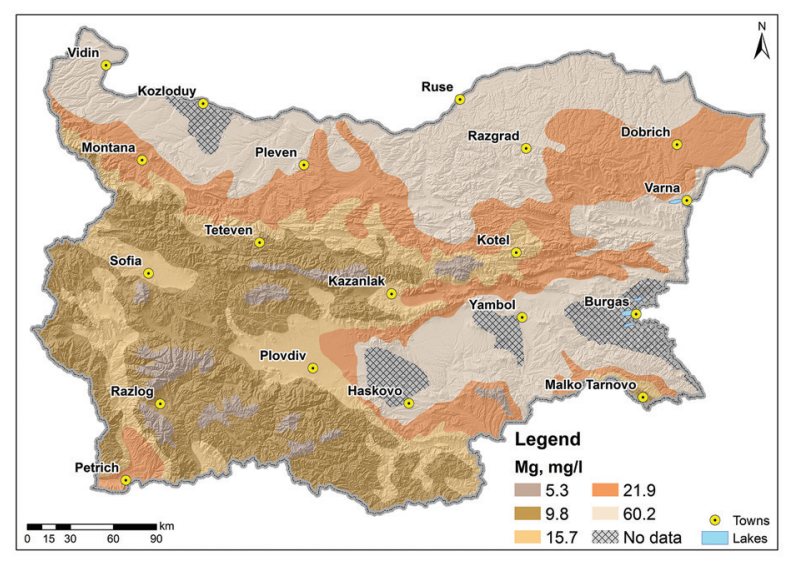

Fig. 6. Average groundwater chemistry in the study area (magnesium).

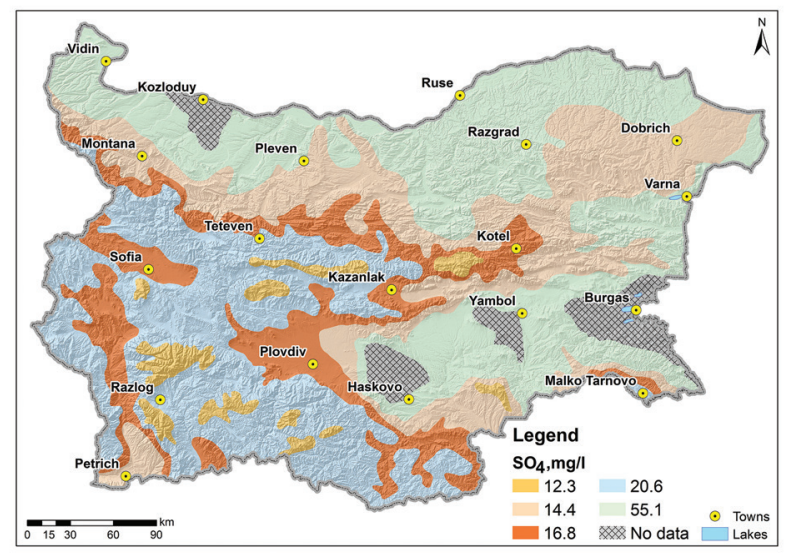

Fig. 8. Average groundwater chemistry in the study area (sulphates).

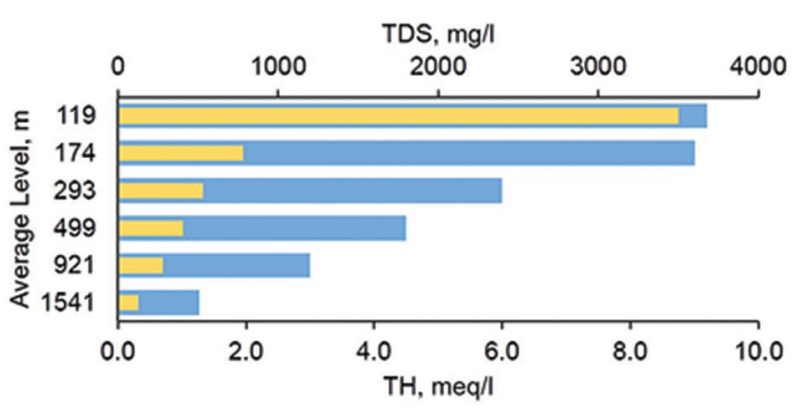

$=\mathrm{TH}, \mathrm{meq} / \mathrm{l}=\mathrm{TDS}, \mathrm{mg} / \mathrm{l}$

Fig. 10. Dependency of the total hardness (TH) and total dissolved solids (TDS) versus average altitude above sea level.

to an increase in the total hardness and sum total of dissolved solids (Fig. 10). Therefore, the ground waters in question can be described as hydrocarbonate with predominant calcium cations.

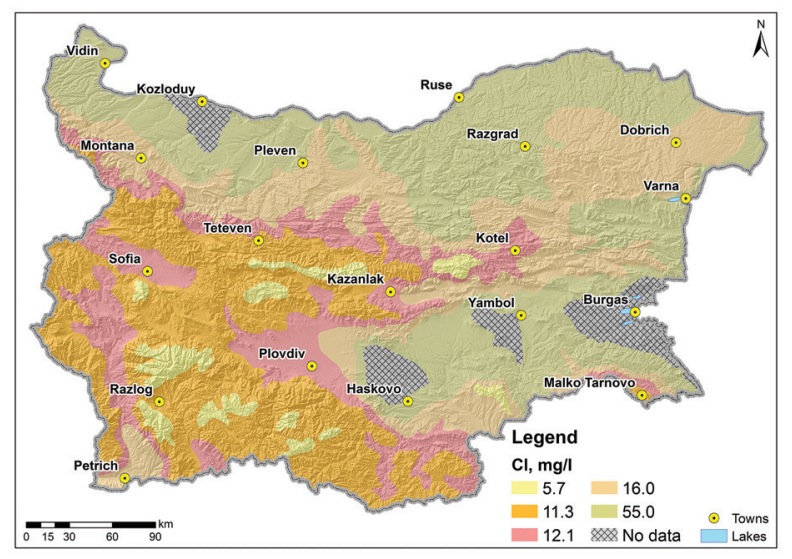

Fig. 7. Average groundwater chemistry in the study area (chlorine).

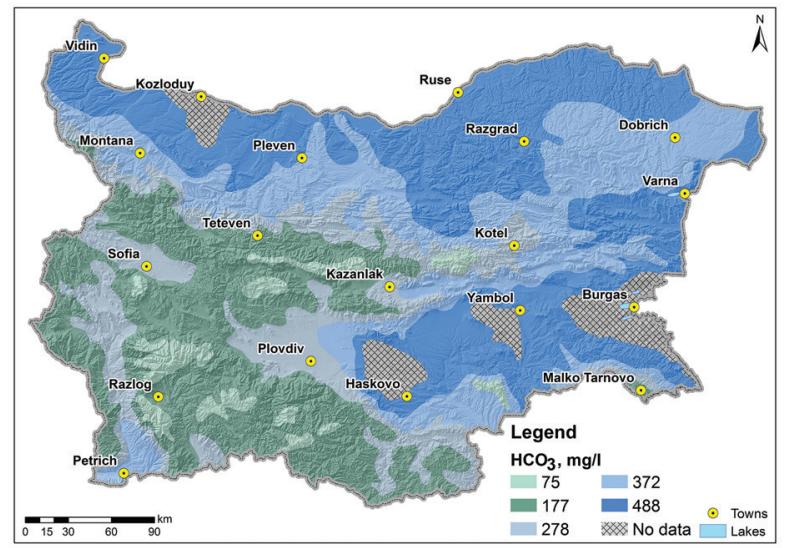

Fig. 9. Average groundwater chemistry in the study area (bicarbonates).

\section{CHEMICAL COMPOSITION AND TYPES OF GROUNDWATER}

\section{Piper diagram and Kurlov equation}

Groundwater is essentially a solution of salts, and its chemical nature, like that of all solutions, is based upon the nature and proportion of the substances it contains. The chemical composition of ground waters, or their type, is represented by the Piper diagram (Piper, 1944) and according to Kurlov's criterion (Pentchev et al., 1990). These diagrams are in fact classifications by means of combining their components.

Piper (1944) classified the water types and their hydrogeochemical appearance by plotting the distribution of major cations and anions that determine the geochemical type of groundwater.

Kurlov equation represents the type of groundwater by an equation, in which anions with concen- 
trations above 5 eq\% are written in a descending order in the numerator, and with concentrations above 5 eq\% the cations are written in a descending order in the denominator. The name of the water type has been determined by the content of anions and cations in concentrations above $20 \mathrm{eq} \%$.

\section{Chadha diagram}

The chart developed by Chadha (1999) gives an overall assessment of the main geochemical processes affecting the formation and composition of groundwater. The Chadha Diagram has been used to classify the various groundwater types and to identify the hydrochemical processes that control water composition. The diagram is a modified version of the Piper Diagram (Hamed et al., 2010), in which both equilateral triangles have been omitted.

\section{GROUNDWATER QUALITY ASSESSMENT METHODOLOGY}

In practice, two approaches can be applied when assessing water quality by its physicochemical indicators: a differentiated one and a complex one. Even though the content of individual substances in water may not exceed the permissible upper limit, yet this does not mean that the water can be classified as being in excellent condition or that it can be used for drinking and domestic water supply. The water quality can also be compromised by the total adverse effects of various substances, which individually have concentrations below the permissible standard.

In the differentiated approach, the condition of groundwater is determined by individual physicochemical indicators. The disadvantage is that it does not give an overall assessment of the water status, while in a complex approach the status of groundwater is determined by multiple indicators, and the final result is presented in the form of a score, ranking or classification. Also, there must be a clear formulation of the rating scale, the application of weight and purpose of the method: indicative, comparative, for categorization, solving a specific scientific or applied problem, etc. The advantage of this approach is that it provides an overall assessment of the quality status of a water body.

The assessment of groundwater quality includes the following main steps: choice of method; selection of the parameters to be included in the assessment; setting the weight of the selected parameters; and classification of groundwater according to the calculated quality index. This article represents a comprehensive approach to assessing the qual- ity of shallow groundwater on the territory of Bulgaria by determining the groundwater quality index (GWQI). In essence, the method for assessing water quality is a weighted arithmetic method, which aims to assess the overall water quality in relation to a number of selected parameters.

The methodology for determining the quality index is described by equations (1) to (5). The evaluation of the quality index is performed according to the equation (1) (Yogendra and Puttaiah, 2008; Jareda, et al., 2016):

$$
\text { GWQI }=\frac{\sum_{\mathrm{i}=1}^{\mathrm{n}} \mathrm{W}_{\mathrm{i}} \times \mathrm{Q}_{\mathrm{i}}}{\sum_{\mathrm{i}=1}^{\mathrm{n}} \mathrm{W}_{\mathrm{i}}},
$$

where $W_{i}$ is the unit weight of each parameter; $Q_{i}$ is a measure of the quality of each parameter; and $n$ is the number of parameters.

The quality rating $\left(Q_{i}\right)$ has been calculated, using the determined average value $\left(M_{i}\right)$ and the permissible maximum value of the parameters $\left(S_{j}\right)$ for the quality of drinking water defined in the national legislation (Regulation No. 9, 2001). The quality rating $\left(Q_{j}\right)$ for each parameter has been calculated, using the equation (2):

$$
\mathrm{Q}_{\mathrm{i}}=100 \times \frac{\left|\mathrm{M}_{\mathrm{i}}-\mathrm{I}_{\mathrm{i}}\right|}{\mathrm{S}_{\mathrm{i}}-\mathrm{I}_{\mathrm{i}}},
$$

where $M_{i}$ is the observed average value of the $\mathrm{i}^{\text {th }}$ parameter; $I_{i}$ is the ideal value in the $i^{\text {th }}$ parameter. The value of zero has been assumed for $I_{i}$, except for the parameters of $\mathrm{pH}(\mathrm{I}=7.0)$ and dissolved oxygen (D.O., I = $14.6 \mathrm{mg} / \mathrm{l}$ ) (Yogendra and Puttaiah, 2008; Jareda et al., 2016). $S_{i}$ is the standard value of the $\mathrm{i}^{\text {th }}$ parameter. In the present study, for the indicators bicarbonate and TDS for the upper limit, the values given in the document of the World Health Organization Guidelines for Drinking-Water Quality (WHO, 2011) were used, as the maximum allowable value for them is missing in Regulation No. 9 (2001).

The unit weight $\left(W_{i}\right)$ of each parameter is inversely proportional to the value of the standard parameter, and it is calculated, using the equation (3) (Mohan et al., 1996) or (4) (Jareda et al., 2016):

$$
\begin{aligned}
& \mathrm{W}_{\mathrm{i}}=\frac{1}{\mathrm{~S}_{\mathrm{i}}} \\
& \mathrm{W}_{\mathrm{i}}=\frac{\mathrm{K}}{\mathrm{S}_{\mathrm{i}}},
\end{aligned}
$$

where $K$ is a proportional constant, which is calculated by the equation (5): 


$$
\mathrm{K}=\frac{1}{\sum_{\mathrm{i}=1}^{\mathrm{n}}\left(\frac{1}{\mathrm{~S}_{\mathrm{i}}}\right)}
$$

Having calculated the GWQI values, the ground waters of Bulgaria were classified into several classes by type and according to their quality. In order to determine the status of groundwater, two classifications with the corresponding five intervals (Brown et al., 1972; Chatterjee and Raziuddin, 2007; Sahu and Sikdar, 2008), have been most commonly used. In this paper, the classification of Brown et al. (1972) and Chatterjee and Raziuddin (2007) was selected as most appropriate according to the calculated quality index (Table 2).

Table 2

Classification of groundwater quality based on WQI (GWQI)drinking water quality rating

\begin{tabular}{ccc}
\hline WQI$^{*}$ & WQI $^{* *}$ & STATUS \\
\hline $0-25$ & $<50$ & Excellent Water \\
$26-50$ & $50-100$ & Good Water \\
$51-75$ & $100-200$ & Poor Water \\
$76-100$ & $200-300$ & Very Poor Water \\
$>100$ & $>300$ & Unfit for drinking \\
\hline
\end{tabular}

*Source: Brown et al. (1972), Chatterjee and Raziuddin (2007) **Source: Sahu and Sikdar (2008)

\section{RESULTS AND DISCUSSION}

\section{Types of groundwater}

\section{Piper diagram and Kurlov equation}

In this study, the types of shallow ground waters on the territory of Bulgaria are classified according to Piper and Kurlov. With regard to cations, waters are mainly rich in calcium ions, with the exception of hard waters, which by cationic composition appear without a dominant type (Fig. 11). With regard to anions, all waters can be described as hydrocarbonate. Hence, the dominant type of groundwater is $\mathrm{Ca}-\mathrm{HCO}_{3}$.

According to Kurlov equation, waters from the hypergenic zone of Bulgaria are hydrocarbonatecalcium-magnesium, with the exception of hard waters, which are hydrocarbonate-magnesium-calcium (Fig. 12). Very soft waters are bicarbonate-calciummagnesium-sodium. Soft waters, moderately hard waters, and rather hard waters are bicarbonate-calcium-magnesium, and hard waters are bicarbonatemagnesium-calcium.

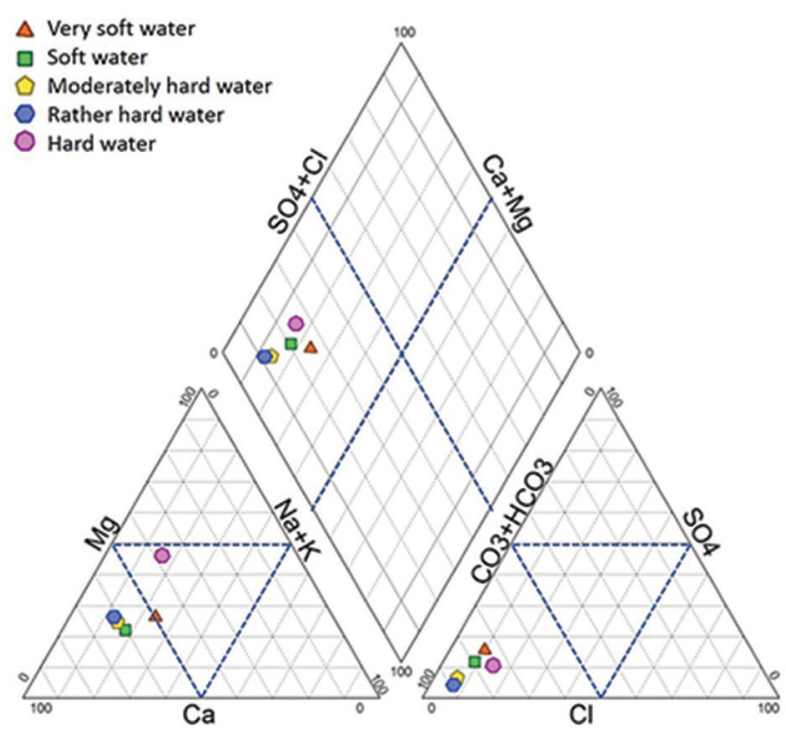

Fig. 11. The Piper diagram of groundwater chemistry in the study area.

\begin{tabular}{|c|c|}
\hline Water types & Kurlov equation \\
\hline \multirow{2}{*}{ very soft } & $\mathrm{HCO}_{3}{ }^{-} 74.675 \mathrm{SO}_{4}^{2{ }^{-}} 15.558 \mathrm{Cl}^{-} 9.767$ \\
\hline & $\mathrm{Ca}^{2+} 49.912 \mathrm{Mg}^{2+} 26.120 \mathrm{Na}^{+} 23.967$ \\
\hline \multirow{2}{*}{ soft } & $\mathrm{HCO}_{3}{ }^{-} 79.509 \mathrm{SO}_{4}^{2{ }^{-}} 11.755 \mathrm{Cl}^{-} 8.736$ \\
\hline & $\mathrm{Ca}^{2+} 63.116 \mathrm{Mg}^{2+} 23.180$ \\
\hline \multirow{2}{*}{ moderately hard } & $\mathrm{HCO}_{3}{ }^{-} 86.830 \mathrm{SO}_{4}^{2-} 6.666 \mathrm{Cl}^{-} 6.504$ \\
\hline & $\mathrm{Ca}^{2+} 61.113 \mathrm{Mg}^{2+} 24.613$ \\
\hline \multirow{2}{*}{ rather hard } & $\mathrm{HCO}_{3}^{-} 89.031 \mathrm{Cl}^{-} 6.590$ \\
\hline & $\overline{\mathrm{Ca}^{2+} 61.283 \mathrm{Mg}^{2+} 26.283}$ \\
\hline \multirow{2}{*}{ hard } & $\mathrm{HCO}_{3}{ }^{-} 74.772 \mathrm{SO}_{4}{ }^{2-} 10.725 \mathrm{Cl}^{-} 14.503$ \\
\hline & $\mathrm{Mg}^{2+} 46.268 \mathrm{Ca}^{2+} 37.847$ \\
\hline
\end{tabular}

Fig. 12. The diagram of groundwater chemistry according to Kurlov equation.

\section{Chadha diagram}

Groundwater from the hypergenic zone is expected to fall into field 5 of the Chadha Diagram, where the water type is $\mathrm{Ca}-\mathrm{Mg}-\mathrm{HCO}_{3}$ (Fig. 13). In this field, the five weak acidic anions $\left(\mathrm{HCO}_{3}{ }^{2-}\right.$ and $\left.\mathrm{CO}_{3}{ }^{-}\right)$exceed the strong acidic anions $\left(\mathrm{Cl}^{-}\right.$and $\left.\mathrm{SO}_{4}^{2-}\right)$. In addition, the alkaline earth metals $\left(\mathrm{Ca}^{2+}\right.$ and $\left.\mathrm{Mg}^{2+}\right)$ exceed the salt alkalis $\left(\mathrm{Na}^{+}\right.$and $\left.\mathrm{K}^{+}\right)$.

\section{Groundwater quality index (GWQI or WQI) - results}

The groundwater quality index for the shallow groundwater was calculated, making use of the spa- 


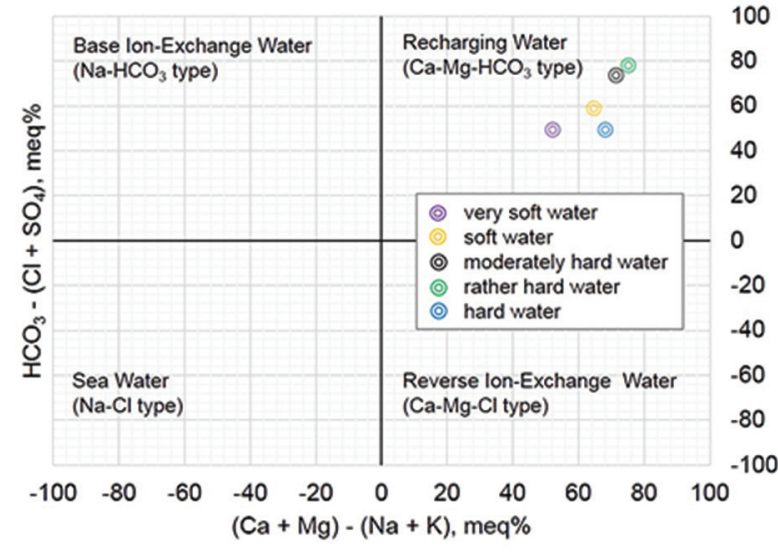

Fig. 13. Chadha diagram showing the groundwater type and the geochemical processes.

tially distributed mean values of the concentration of the individual major ions in the groundwater of Bulgaria according to Kehajov (1968). To determine the quality of groundwater, equation (1) and equation (4) were used to calculate the weight of the individual parameters at a constant $\mathrm{K}=7.947$
(Table 3). Using equation (3) in order to determine the weight of the individual parameters, the calculations for GWQI are listed in Table 4.

The groundwater quality index varies from 13 to 92 (Fig. 14). These values indicate that the water can be used for drinking purposes, i.e., there is no excess of the critical value of 100 , above which the water is deemed unsuitable for drinking. Using the classifications of Brown et al. (1972) and Chatterjee and Raziuddin (2007), shallow groundwater on the territory of Bulgaria can be classified in the following manner: waters of excellent quality ( $3 \%$ of the studied area); waters of good quality (39\%); waters of poor quality (22\%); and waters of very poor quality $31 \%$ of the studied area (see Table 5). In Kehajov's (1968) paper, for about 5\% of the groundwater in the hypergenic zone (corresponding to very hard water) no data was presented.

For the territory of Bulgaria, the groundwater quality index has the lowest values in the high mountainous regions (Table 5), where water exchange is most intensive. In these areas, the hypergenic zone is always well washed. This is an ultra-fresh water exchange zone - or these are areas with rapid chem-

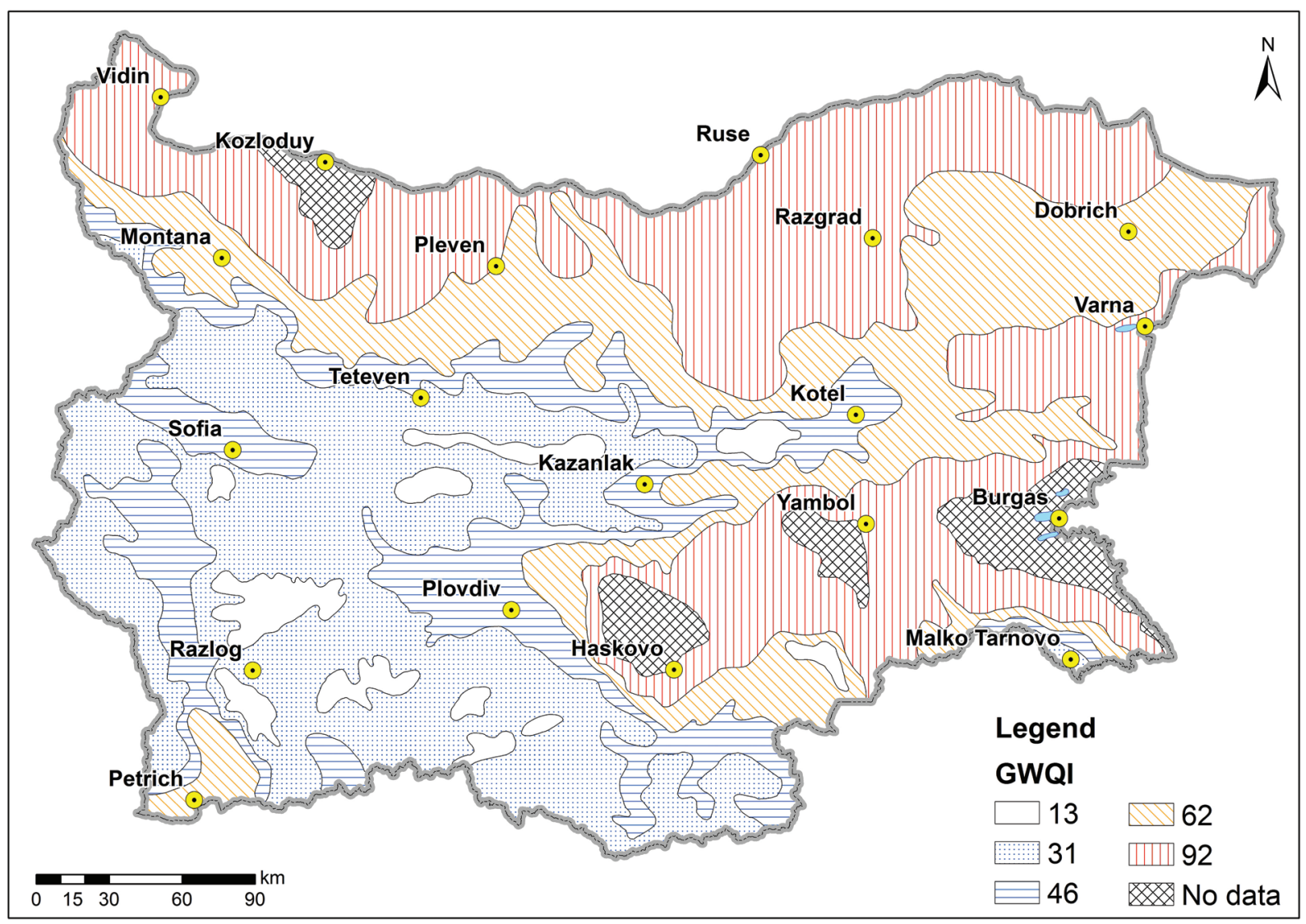

Fig. 14. Spatial distribution of GWQI in the study area. 
Table 3

Weights for determining the groundwater parameters, and its quality index for the study area

\begin{tabular}{|c|c|c|c|c|c|c|c|}
\hline & & & & & & \multicolumn{2}{|c|}{ Constant $\mathrm{K}=7.947$} \\
\hline Type & Parameters & $\begin{array}{c}\text { Average value, } \\
\text { mg/l }\end{array}$ & Regulation No9 & Weight, $\mathrm{W}_{\mathrm{i}}=\mathrm{K} / \mathrm{S}_{\mathrm{i}}$ & $\mathrm{Q}_{\mathrm{i}}$ & $\mathrm{W}_{\mathrm{i}} \times \mathrm{Q}_{\mathrm{i}}$ & Status** \\
\hline \multirow{10}{*}{ 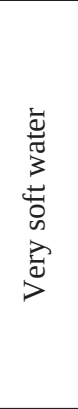 } & $\mathrm{Na}+\mathrm{K}, \mathrm{mg} / \mathrm{l}$ & 9.2 & 200 & 0.040 & 4.600 & 0.183 & \multirow{10}{*}{ 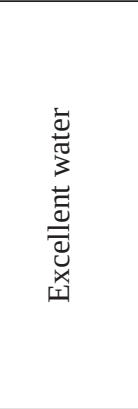 } \\
\hline & $\mathrm{Ca}, \mathrm{mg} / \mathrm{l}$ & 16.7 & 150 & 0.053 & 11.133 & 0.590 & \\
\hline & $\mathrm{Mg}, \mathrm{mg} / \mathrm{l}$ & 5.3 & 80 & 0.099 & 6.625 & 0.658 & \\
\hline & Cl, mg/l & 5.7 & 250 & 0.032 & 2.280 & 0.072 & \\
\hline & $\mathrm{SO}_{4}, \mathrm{mg} / \mathrm{l}$ & 12.3 & 250 & 0.032 & 4.920 & 0.156 & \\
\hline & $\mathrm{HCO}_{3}, \mathrm{mg} / \mathrm{l}$ & 75 & $120 *$ & 0.066 & 62.500 & 4.139 & \\
\hline & $\mathrm{TH}, \mathrm{meq} / \mathrm{l}$ & 1.269 & 12 & 0.662 & 10.575 & 7.003 & \\
\hline & TDS, mg/l & 124.2 & $500 *$ & 0.016 & 24.840 & 0.395 & \\
\hline & & & Sum $=$ & 1.000 & \multirow{2}{*}{\multicolumn{2}{|c|}{$\begin{array}{c}13 \\
\text { GWQI = } 13 / 1=13\end{array}$}} & \\
\hline & & & & & & & \\
\hline \multirow{10}{*}{ 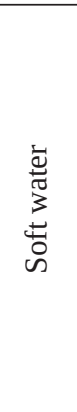 } & $\mathrm{Na}+\mathrm{K}, \mathrm{mg} / \mathrm{l}$ & 14.8 & 200 & 0.040 & 7.400 & 0.294 & \multirow{20}{*}{ 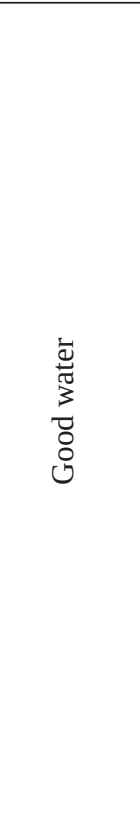 } \\
\hline & $\mathrm{Ca}, \mathrm{mg} / \mathrm{l}$ & 44 & 150 & 0.053 & 29.333 & 1.554 & \\
\hline & Mg, mg/l & 9.8 & 80 & 0.099 & 12.250 & 1.217 & \\
\hline & $\mathrm{Cl}, \mathrm{mg} / \mathrm{l}$ & 11.3 & 250 & 0.032 & 4.520 & 0.144 & \\
\hline & $\mathrm{SO}_{4}, \mathrm{mg} / \mathrm{l}$ & 20.6 & 250 & 0.032 & 8.240 & 0.262 & \\
\hline & $\mathrm{HCO}_{3}, \mathrm{mg} / \mathrm{l}$ & 177 & $120 *$ & 0.066 & 147.500 & 9.768 & \\
\hline & $\mathrm{TH}, \mathrm{meq} / \mathrm{l}$ & 3 & 12 & 0.662 & 25.000 & 16.556 & \\
\hline & \multirow{3}{*}{ TDS, mg/l } & \multirow{3}{*}{277.5} & $500 *$ & 0.016 & \multirow{2}{*}{55.500} & \multirow{2}{*}{$\begin{array}{c}0.882 \\
31\end{array}$} & \\
\hline & & & \multirow[t]{2}{*}{ Sum $=$} & \multirow[t]{2}{*}{1.000} & & & \\
\hline & & & & & \multicolumn{2}{|c|}{ GWQI = 31/1 = 31} & \\
\hline \multirow{10}{*}{ 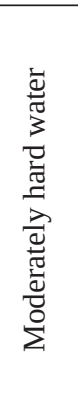 } & $\mathrm{Na}+\mathrm{K}, \mathrm{mg} / \mathrm{l}$ & 17.2 & 200 & 0.040 & 8.600 & 0.342 & \\
\hline & $\mathrm{Ca}, \mathrm{mg} / \mathrm{l}$ & 64.3 & 150 & 0.053 & 42.867 & 2.271 & \\
\hline & Mg, mg/l & 15.7 & 80 & 0.099 & 19.625 & 1.950 & \\
\hline & $\mathrm{Cl}, \mathrm{mg} / \mathrm{l}$ & 12.1 & 250 & 0.032 & 4.840 & 0.154 & \\
\hline & $\mathrm{SO}_{4}, \mathrm{mg} / \mathrm{l}$ & 16.8 & 250 & 0.032 & 6.720 & 0.214 & \\
\hline & $\mathrm{HCO}_{3}, \mathrm{mg} / \mathrm{l}$ & 278 & $120 *$ & 0.066 & 231.667 & 15.342 & \\
\hline & $\mathrm{TH}, \mathrm{meq} / \mathrm{l}$ & 4.5 & 12 & 0.662 & 37.500 & 24.834 & \\
\hline & TDS, mg/l & 404.1 & $500 *$ & 0.016 & 80.820 & 1.285 & \\
\hline & & & Sum $=$ & 1.000 & & 46 & \\
\hline & & & & & GW & $=46 / 1=46$ & \\
\hline & $\mathrm{Na}+\mathrm{K}, \mathrm{mg} / \mathrm{l}$ & 19.6 & 200 & 0.040 & 9.800 & 0.389 & \\
\hline & $\mathrm{Ca}, \mathrm{mg} / \mathrm{l}$ & 84.2 & 150 & 0.053 & 56.133 & 2.974 & \\
\hline 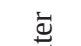 & $\mathrm{Mg}, \mathrm{mg} / \mathrm{l}$ & 21.9 & 80 & 0.099 & 27.375 & 2.719 & \\
\hline$\frac{\pi}{3}$ & $\mathrm{Cl}, \mathrm{mg} / \mathrm{l}$ & 16 & 250 & 0.032 & 6.400 & 0.203 & 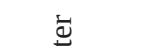 \\
\hline F & $\mathrm{SO}_{4}, \mathrm{mg} / \mathrm{l}$ & 14.4 & 250 & 0.032 & 5.760 & 0.183 & $\frac{\pi}{3}$ \\
\hline 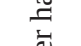 & $\mathrm{HCO}_{3}, \mathrm{mg} / \mathrm{l}$ & 372 & $120 *$ & 0.066 & 310.000 & 20.530 & ठั \\
\hline$\cong$ & $\mathrm{TH}, \mathrm{meq} / \mathrm{l}$ & 6 & 12 & 0.662 & 50.000 & 33.113 & $\stackrel{2}{2}$ \\
\hline$\widetilde{\sim}$ & TDS, mg/l & 528.1 & $500 *$ & 0.016 & 105.620 & 1.679 & \\
\hline & & & Sum $=$ & 1.000 & & 62 & \\
\hline & & & & & GW & $=62 / 1=92$ & \\
\hline & $\mathrm{Na}+\mathrm{K}, \mathrm{mg} / \mathrm{l}$ & 39.1 & 200 & 0.040 & 19.550 & 0.777 & \\
\hline & $\mathrm{Ca}, \mathrm{mg} / \mathrm{l}$ & 81.2 & 150 & 0.053 & 54.133 & 2.868 & \\
\hline & $\mathrm{Mg}, \mathrm{mg} / \mathrm{l}$ & 60.2 & 80 & 0.099 & 75.250 & 7.475 & $\bar{d}$ \\
\hline$\ddot{\Xi}$ & $\mathrm{Cl}, \mathrm{mg} / \mathrm{l}$ & 55 & 250 & 0.032 & 22.000 & 0.699 & $\frac{\overrightarrow{0}}{3}$ \\
\hline$\frac{\pi}{3}$ & $\mathrm{SO}_{4}, \mathrm{mg} / \mathrm{l}$ & 55.1 & 250 & 0.032 & 22.040 & 0.701 & 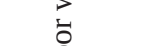 \\
\hline 司 & $\mathrm{HCO}_{3}, \mathrm{mg} / \mathrm{l}$ & 488 & $120 *$ & 0.066 & 406.667 & 26.932 & 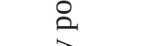 \\
\hline $\mathbf{I}$ & $\mathrm{TH}, \mathrm{meq} / \mathrm{l}$ & 9 & 12 & 0.662 & 75.000 & 49.669 & $\vec{d}$ \\
\hline & TDS, mg/l & 778.6 & $500 *$ & 0.016 & 155.720 & 2.475 & $>$ \\
\hline & & & Sum $=$ & 1.000 & & 92 & \\
\hline & & & & & GW & $=92 / 1=92$ & \\
\hline
\end{tabular}

*Source: WHO (2011)

**Source: Brown et al. (1972), Chatterjee and Raziuddin (2007) 
Table 4

Weighting used for determining the groundwater parameters, and its quality index for the study area

\begin{tabular}{|c|c|c|c|c|c|c|c|}
\hline Type & Parameters & $\begin{array}{c}\text { Average } \\
\text { value, } \mathrm{mg} / \mathrm{l}\end{array}$ & Regulation No9 & Weight, $\mathrm{W}_{\mathrm{i}}=1 / \mathrm{S}_{\mathrm{i}}$ & $\mathrm{Q}_{\mathrm{i}}$ & $\mathrm{W}_{\mathrm{i}} \times \mathrm{Q}_{\mathrm{i}}$ & Status** \\
\hline \multirow{10}{*}{ 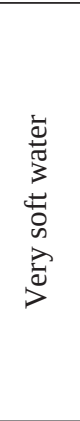 } & $\mathrm{Na}+\mathrm{K}, \mathrm{mg} / \mathrm{l}$ & 9.2 & 200 & 0.005 & 4.600 & 0.023 & \multirow{10}{*}{ 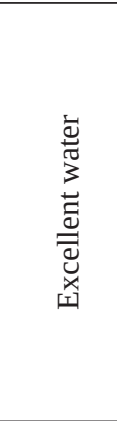 } \\
\hline & $\mathrm{Ca}, \mathrm{mg} / \mathrm{l}$ & 16.7 & 150 & 0.007 & 11.133 & 0.074 & \\
\hline & $\mathrm{Mg}, \mathrm{mg} / \mathrm{l}$ & 5.3 & 80 & 0.013 & 6.625 & 0.083 & \\
\hline & $\mathrm{Cl}, \mathrm{mg} / \mathrm{l}$ & 5.7 & 250 & 0.004 & 2.280 & 0.009 & \\
\hline & $\mathrm{SO}_{4}, \mathrm{mg} / \mathrm{l}$ & 12.3 & 250 & 0.004 & 4.920 & 0.020 & \\
\hline & $\mathrm{HCO}_{3}, \mathrm{mg} / \mathrm{l}$ & 75 & $120 *$ & 0.008 & 62.500 & 0.521 & \\
\hline & TH, meq/l & 1.269 & 12 & 0.083 & 10.575 & 0.882 & \\
\hline & TDS, mg/l & 124.2 & $500 *$ & 0.002 & 24.840 & 0.050 & \\
\hline & & & Sum $=$ & 0.126 & & 1.661 & \\
\hline & & & & & GWQI = & $.126=13$ & \\
\hline \multirow{10}{*}{ 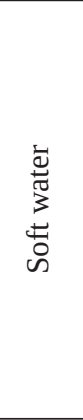 } & $\mathrm{Na}+\mathrm{K}, \mathrm{mg} / \mathrm{l}$ & 14.8 & 200 & 0.005 & 7.400 & 0.037 & \multirow{20}{*}{ 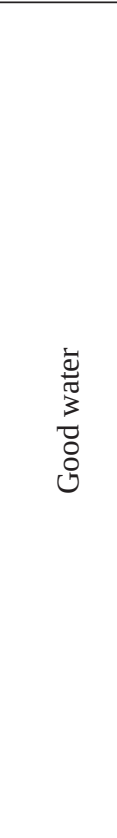 } \\
\hline & $\mathrm{Ca}, \mathrm{mg} / \mathrm{l}$ & 44 & 150 & 0.007 & 29.333 & 0.196 & \\
\hline & $\mathrm{Mg}, \mathrm{mg} / \mathrm{l}$ & 9.8 & 80 & 0.013 & 12.250 & 0.153 & \\
\hline & $\mathrm{Cl}, \mathrm{mg} / \mathrm{l}$ & 11.3 & 250 & 0.004 & 4.520 & 0.018 & \\
\hline & $\mathrm{SO}_{4}, \mathrm{mg} / \mathrm{l}$ & 20.6 & 250 & 0.004 & 8.240 & 0.033 & \\
\hline & $\mathrm{HCO}_{3}, \mathrm{mg} / \mathrm{l}$ & 177 & $120 *$ & 0.008 & 147.500 & 1.229 & \\
\hline & $\mathrm{TH}, \mathrm{meq} / \mathrm{l}$ & 3 & 12 & 0.083 & 25.000 & 2.085 & \\
\hline & TDS, mg/l & 277.5 & $500 *$ & 0.002 & 55.500 & 0.111 & \\
\hline & & & Sum $=$ & 0.126 & & 3.862 & \\
\hline & & & & & \multicolumn{2}{|c|}{ GWQI $=3.862 / 0.126=31$} & \\
\hline \multirow{10}{*}{ 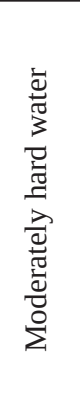 } & $\mathrm{Na}+\mathrm{K}, \mathrm{mg} / \mathrm{l}$ & 17.2 & 200 & 0.005 & 8.600 & 0.043 & \\
\hline & $\mathrm{Ca}, \mathrm{mg} / \mathrm{l}$ & 64.3 & 150 & 0.007 & 42.867 & 0.286 & \\
\hline & $\mathrm{Mg}, \mathrm{mg} / \mathrm{l}$ & 15.7 & 80 & 0.013 & 19.625 & 0.245 & \\
\hline & $\mathrm{Cl}, \mathrm{mg} / \mathrm{l}$ & 12.1 & 250 & 0.004 & 4.840 & 0.019 & \\
\hline & $\mathrm{sO} 4, \mathrm{mg} / \mathrm{l}$ & 16.8 & 250 & 0.004 & 6.720 & 0.027 & \\
\hline & HCO3, mg/l & 278 & $120 *$ & 0.008 & 231.667 & 1.931 & \\
\hline & $\mathrm{TH}, \mathrm{meq} / \mathrm{l}$ & 4.5 & 12 & 0.083 & 37.500 & 3.125 & \\
\hline & TDS, mg/l & 404.1 & $500 *$ & 0.002 & 80.820 & 0.162 & \\
\hline & & & Sum $=$ & 0.126 & & 5.838 & \\
\hline & & & & & GWQI = & $.126=46$ & \\
\hline \multirow{10}{*}{ 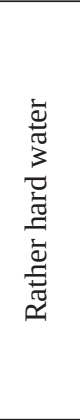 } & $\mathrm{Na}+\mathrm{K}, \mathrm{mg} / \mathrm{l}$ & 19.6 & 200 & 0.005 & 9.800 & 0.049 & \multirow{10}{*}{ 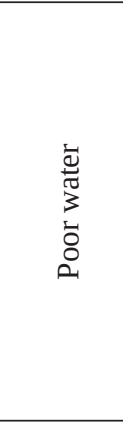 } \\
\hline & $\mathrm{Ca}, \mathrm{mg} / \mathrm{l}$ & 84.2 & 150 & 0.007 & 56.133 & 0.374 & \\
\hline & $\mathrm{Mg}, \mathrm{mg} / \mathrm{l}$ & 21.9 & 80 & 0.013 & 27.375 & 0.342 & \\
\hline & $\mathrm{Cl}, \mathrm{mg} / \mathrm{l}$ & 16 & 250 & 0.004 & 6.400 & 0.026 & \\
\hline & $\mathrm{sO} 4, \mathrm{mg} / \mathrm{l}$ & 14.4 & 250 & 0.004 & 5.760 & 0.023 & \\
\hline & HCO3, mg/l & 372 & $120 *$ & 0.008 & 310.000 & 2.583 & \\
\hline & TH, meq/l & 6 & 12 & 0.083 & 50.000 & 4.169 & \\
\hline & TDS, mg/l & 528.1 & $500 *$ & 0.002 & 105.620 & 0.211 & \\
\hline & & & Sum $=$ & 0.126 & & 7.778 & \\
\hline & & & & & GWQI = & $.126=62$ & \\
\hline \multirow{10}{*}{ 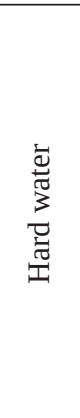 } & $\mathrm{Na}+\mathrm{K}, \mathrm{mg} / \mathrm{l}$ & 39.1 & 200 & 0.005 & 19.550 & 0.098 & \multirow{10}{*}{ 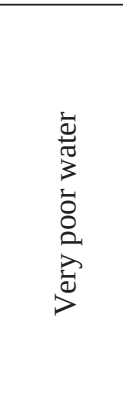 } \\
\hline & Ca, mg/l & 81.2 & 150 & 0.007 & 54.133 & 0.361 & \\
\hline & Mg, mg/l & 60.2 & 80 & 0.013 & 75.250 & 0.941 & \\
\hline & $\mathrm{Cl}, \mathrm{mg} / \mathrm{l}$ & 55 & 250 & 0.004 & 22.000 & 0.088 & \\
\hline & $\mathrm{sO} 4, \mathrm{mg} / \mathrm{l}$ & 55.1 & 250 & 0.004 & 22.040 & 0.088 & \\
\hline & HCO3, mg/l & 488 & $120 *$ & 0.008 & 406.667 & 3.389 & \\
\hline & $\mathrm{TH}, \mathrm{meq} / \mathrm{l}$ & 9 & 12 & 0.083 & 75.000 & 6.254 & \\
\hline & TDS, mg/l & 778.6 & $500 *$ & 0.002 & 155.720 & 0.311 & \\
\hline & & & Sum $=$ & 0.126 & & 11.530 & \\
\hline & & & & & GWQI = 1 & $.126=92$ & \\
\hline
\end{tabular}

*Source: WHO (2011)

**Source: Brown et al. (1972), Chatterjee and Raziuddin (2007) 
Table 5

Overview of the results regarding GWQI

\begin{tabular}{lcclc}
\hline \multicolumn{1}{c}{ Water type } & Average level*, m & Result & Status** & $\begin{array}{c}\text { \% of Bulgarian } \\
\text { territory }\end{array}$ \\
\hline Very soft water & 1541 & 13 & Excellent & 3 \\
Soft water & 921 & 31 & Good & 24 \\
Moderately hard water & 499 & 46 & Good & 15 \\
Rather hard water & 293 & 62 & Poor & 22 \\
Hard water & 174 & 92 & Very poor & 31 \\
Very hard water & 119 & No data & - & 5 \\
\hline
\end{tabular}

*Source: DEM 50 m

**Source: Brown et al. (1972), Chatterjee and Raziuddin (2007)

ical erosion (Kehajov, 1968). Conversely, the higher values of the groundwater quality index are in the lower hypsometric zone of the country (Fig. 15a, $b$ ), in the aeration zone of which large amounts of salts of alkali $\left(\mathrm{Na}^{+}\right.$and $\mathrm{K}^{+}$ions) and alkaline earth metals have accumulated $\left(\mathrm{Ca}^{2+}\right.$ and $\mathrm{Mg}^{2+}$ ions). These are mostly areas with slow chemical erosion (Kehajov, 1968).

The composition of groundwater is determined by the concentration of dissolved salts in the water itself. The composition depends on the characteristics of the rocks, with which the water has been, or is presently, in contact, as well as on the rock-water interaction, so the composition of the rock is very important for the quality of groundwater. The cations content in groundwater depends primarily on the mineral composition of the rock.

\section{CONCLUSION}

The construction of a method for assessing the groundwater quality depends on the quantity and quality of the source information; the application of weighting or arranging according to certain criteria of the indicators used (classified as harmful, less harmful, primary, secondary); and the state of the existing regulatory framework. The geological setting, typical for the country should also be taken into consideration. A precise wording of the rating scale, and the number and type of physical-chemical parameters is also very important, i.e., they might exert a greater or lesser effect on the quality of water. In this study, for the calculation of a groundwater quality index, only publicly available data about the macro ions has been used. It is advisable, however, to have other data included as well, such as information regarding the micro- and meso-ions.

The groundwater quality index varies in the range of 13 to 92, and should be below the critical value of 100 , above which the water is considered unsuitable for drinking purposes. In conclusion, the shallow ground waters on the territory of Bulgaria can be classified in the range of being waters of excellent quality to waters of very poor quality.
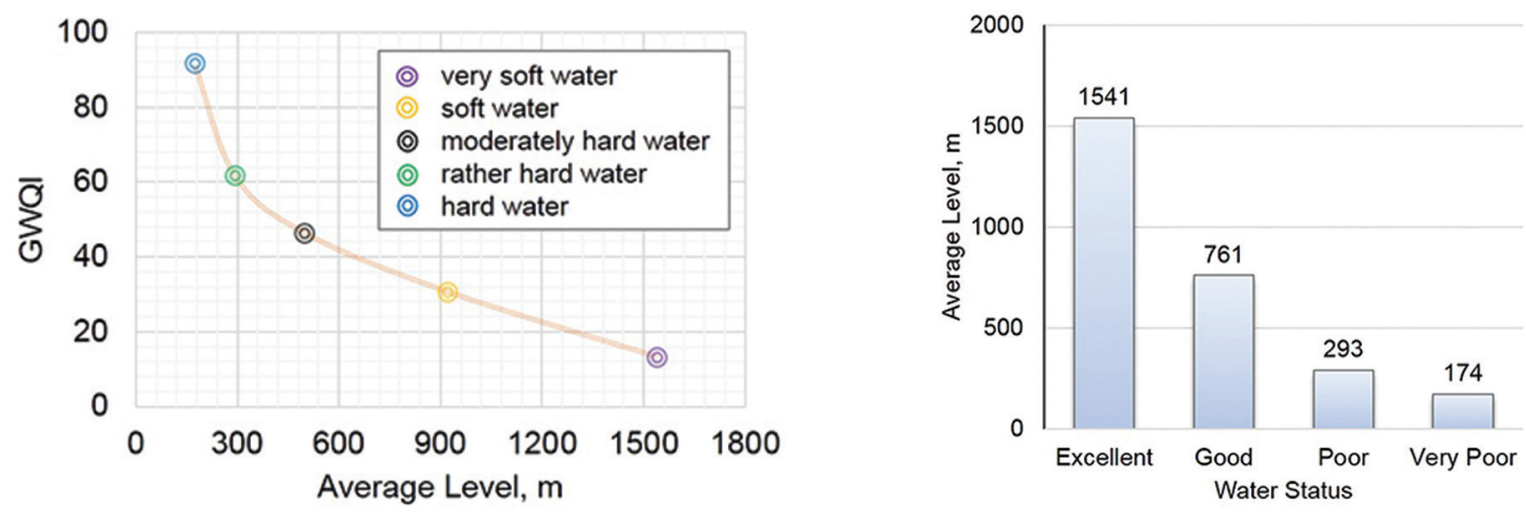

Fig. 15. Dependence of GWQI versus the average altitude $(a)$ and water status versus the average altitude above sea level $(b)$. 
The method for groundwater quality assessment shown here is a simple calculation model that provides an integrated and more thorough picture of groundwater quality. Determining the GWQI is one way of showing the state of groundwater as a cumulatively derived numerical expression, the resulting final number providing a certain status, or grouping the waters into certain quality classes. The index can be useful in assessing the condition of groundwater not only by specialists, but also by the Basin Directorates in assessing the overall quality of the groundwater body on the territory of Bulgaria.

The present study is based only upon publicly available information, and shows its applicability for regional hydro-chemical assessments. This methodology could also be used for up-to-date as- sessments of the groundwater quality in Bulgaria and its changes in the course of time, when current data is supplied by interested institutions, such as the Ministry of Environment and Waters, and the Basin Directorates.

\section{Acknowledgements}

This work was carried out within the framework of the National Scientific Program "Environmental Protection and Reduction of the Risk of Adverse Events and Natural Disasters", approved by Decision of the Council of Ministers № 577/17.08.2018, and supported by the Ministry of Education and Science, Republic of Bulgaria (Agreement No. D01322/18.12.2019). Special gratitude should also be extended to all participants in the reviewing process.

\section{REFERENCES}

Antonov, H., Boyadjiev, N., Danchev, D., Iliev, I., Petrov, P., Plotnikov, N. 1960. Map of the hydrogeological division of Bulgaria 1:600 000. Travaux sur la Géologie de Bulgarie, Série Géologie et Hydrogéologie 1, 212 pp. (in Bulgarian).

Brown, R.M., McCleiland, N.J., Deininger, R.A., O’Connor, M.F. 1972. A water quality index - crossing the psychological barrier. Proceedings of the International Conference on Water Pollution Research, Jerusalem 6, 787-797.

Chadha, D.K., 1999. A proposed new diagram for geochemical classification of natural waters and interpretation of chemical data. Hydrogeology Journal 7, 431-439.

Chatterjee, P.R., Raziuddin, M. 2007. Studies on the water quality of a water body at Asansol town, West Bengal. Nature Environment and Pollution Technology 6 (2), 289-292.

Cheshitev, G., Kanchev, I. (Eds). 1989. Geological map of Bulgaria 1:500 000. Committee on Geology of Bulgaria, Company for Geophysical Surveys and Geological Mapping, Sofia.

Dabovski, H., Boyanov, I., Khrischev, K., Nikolov, T., Sapunov, I., Yanev, Y., Zagorchev, I. 2002. Structure and Alpine evolution of Bulgaria. Geologica Balcanica 32 (2-4), 9-15.

Elango, L., Kannan, R. 2007. Chapter 11. Rock-water interaction and its control on chemical composition of groundwater. In: Sarkar, D., Datta, R., Hannigan, R. (Eds), Concepts and Applications in Environmental Geochemistry. Developments in Environmental Science 5, 229-243.

Gerginov, P., Kerestedjian, T., Toteva, A., Mihaylova, B., Benderev, A. 2019. Geological setting, qualities of groundwater, and legal regulations. Water Affairs Magazine 5-6, 19-29 (in Bulgarian).

Hamed, Y., Dassi, L., Tarki, M., Ahmadi, R, Mehdi, K., Dhia, H.B. 2010. Groundwater origins and mixing pattern in the multilayer aquifer system of the Gafsa-south mining district: A chemical and isotopic approach. Environmental Earth Sciences, DOI 10.1007/s12665-010-0806-x, pp. 1355-1368.
Jareda, G., Dhekne, P.Y., Mahapatral, S.P. 2016. Water quality index and heavy metal pollution index of Bailadila iron ore mine area and its peripherals. International Journal of Engineering and Applied Sciences 3 (12), 80-86.

Kehajov, T. 1968. La Dureté des eaux souterrraines en Bulgarie. Geological Institute of the Bulgarian Academy of Sciences and the Committee of Geology, Jubilee Geological Volume, 447-456 (in Bulgarian, with French abstract).

Kehajov, T. 1970. An attempt at determining the mineral discharge of ground waters in Bulgaria. Proceedings of the Scientific Institute of Geological Research 4, 5-16 (in Bulgarian).

Kehajov, T. 1972. On the altitudinal zonality of fresh water mineralization in the zones of active recharge in Bulgaria. Publications of the Geological Institute, Engineering Geology and Hydrogeology 19-20, 187-177 (in Bulgarian).

Kehajov, T. 1978. Regularities in the territorial distribution of chlorine in the fresh groundwater of Bulgaria. Annual of the Higher Institute of Mining and Geology 24 (4), 233-238 (in Bulgarian).

Kehajov, T. 1979a. Specific features of the regional hydrochemical background of chlorine in Bulgaria. Engineering Geology and Hydrogeology 8-9, 53-61 (in Bulgarian).

Kehajov, T. 1979b. Some data in connection with environmental pollution and mineralization of groundwater in Bulgaria. National Scientific and Technical Conference "Protection of Groundwater from Pollution”, 36-28 (in Russian).

Kehajov, T. 1981. Some features of the macrochemical background of underground waters from the zone of free level aquifers in the country. Review of the Bulgarian Geological Society 42 (2), 245-253 (in Bulgarian, with an abstract in English).

Kehajov, T. 1982. Atlas: Hydrogeochemical maps of ground waters from the hypergenic zones of the Republic of Bulgaria in scale 1:100 000. Scientific Institute of Mineral Research, Committee of Geology, Sofia (in Bulgarian). 
Kehajov, T. 1984a. Maps of the macrochemical composition of ground waters in Bulgaria, Annual of the Committee of Geology 24, 137-148 (in Bulgarian).

Kehajov, T. 1984b. Material discharge of the ground waters in Bulgaria. Annual of the Committee of Geology 24, 149-157 (in Bulgarian).

Kehajov, T., Benderev, A., Hristov, V. 2002. Quality composition and sources of pollution in groundwater. Mining Business and Geology 7-8, 46-51 (in Bulgarian).

Koleva, E., Peneva, R. 1990. Climate Guide. Precipitation in Bulgaria. Bulgarian Academy of Sciences, Sofia, 169 pp. (in Bulgarian).

Kyuchukova, M. 1983. Climate Guide of the Republic of Bulgaria. Volume 3. Temperature of the Air, Temperature of the Soil, Frost. Bulgarian Academy of Sciences, Sofia, 440 pp. (in Bulgarian).

Lyochev, I., Gitzova, S., Mautner, G., Angelieva, R. 1968. Composition of the drinking waters of Bulgaria. Meditsina i fizkultura, Sofia, 147 pp. (in Bulgarian).

Malov, A.I. 2004. Water-Rock Interaction in Vendian SandyClayey Rocks of the Mezen Syneclise. Lithology and Mineral Resources 39 (4), 345-356.

Minkov, M. 1968. Loess in Northern Bulgaria. Complex Investigation. Bulgarian Academy of Sciences Publishing House, Sofia, 202 pp. (in Bulgarian).

Mohan, S.V., Nithila, P., Reddy, S.J. 1996. Estimation of Heavy Metals in Drinking Water and Development of Heavy Met- al Pollution Index. Journal of Environmental Science and Health A31 (2), 283-289.

Pentchev, P., Borisov, S., Velikov, B., Lakov, A., Spasov, K. 1990. Hydrogeology and the basics of engineering geology. Tehnika, Sofia, $342 \mathrm{pp}$.

Piper, A.M. 1944. A graphic procedure in the geochemical interpretation of water analysis. American Geophysical Union Transactions 25, 914-928.

Regulation No.9 of 16 March 2001 Regarding the Quality of Drinking Water, Amended by State Gazette 102 of 12 December 2014 (in Bulgarian).

Sahu, P., Sikdar, P.K. 2008. Hydrochemical framework of the aquifer in and around East Kolkata wetlands, West Bengal, India. Environmental Geology 55, 823-835.

Stefanov, J. (Ed.). 1979. Composition of drinking water in Bulgaria. Meditsina i fizkultura, Sofia, 225 pp. (in Bulgarian).

Stoyanov, N. 2019. Mathematical Modeling in Hydrogeology. Solving Applied Problems with Numerical 3D Models by the Finite Difference Method. Vanyo Nedkov Publishing House, Sofia, 247 pp. (in Bulgarian).

World Health Organization (WHO). 2011. Guidelines for Drinking-Water Quality, Fourth ed. (Geneva, Switzerland).

Yogendra, K., Puttaiah, E.T. 2008. Determination of Water Quality Index and Suitability of an Urban Waterbody in Shimoga Town, Karnataka. Proceedings of Taal2007: The $12^{\text {th }}$ World Lake Conference, 342-346. 